\title{
A Behavioral Perspective for Cognitive Biases Between Financial Experts and Investors: Empirical Evidences of Taiwan Market
}

\author{
Hung-Ta Lee \\ National Taipei University \\ E-Mail: perry@mail.entiesf.com.tw \\ Chuang-Yuang Lin \\ National Taipei University \\ E-Mail: cylin46@hotmail.com
}

\begin{abstract}
This empirical study tests the hypothesis of whether the good stocks are the socalled good corporations or not. Based upon the concepts of behavioral finance, the capital markets are highly complex and uncertain. Suppose the investors focus on the fixed rules and intuitions to make decisions, cognitive biases exist. Since financial experts have lower cognitive biases than investors because of their financial and professional capabilities, the good stocks they selected should perform better in capital markets. Actually, they do not, which indicating the criteria to select good corporations and good stocks are different.
\end{abstract}

JEL classification: G11; G12; G14

Keywords: Behavioral Finance, Benchmark Enterprises, Cognitive Biases, Efficient Market, Quality of Management

\section{INTRODUCTION}

The most important task for corporate managers is to maximize the shareholder values. Hence, the managers engage the behaviors to improve the performance of the corporation. Jensen (1986) suggests the agency problem and identifies the self-interest motives of managers that will somewhat hurt the wealth of shareholders. If the 
environmental situations corporate managers faced are different than the assumptions they formed, a psychological conflict will arise, making the decisions difficult and inconsistent. This kind of psychological phenomenon for individuals is called cognitive biases (Kahneman and Tversky, 1973, 1979). To investors, the existence of cognitive biases will distort the choice of stock selection. Solt and Statman (1989) find investors will take the price-earnings ratio and book-to-market ratio as the indicators for a growth stock, and the stocks that have good growth opportunity will be good corporations. Thus, if the corporations perform excellently in profitability, innovation, management, and marketing, the stocks will be a better choice for investors in the capital market. Solt and Statman (1989) suggest that, under the condition of representative heuristics and cognitive biases, investors will overestimate the possibilities that a growth corporation will also be a growth stock; that is, the excess return for a stock that has high Tobin $\mathrm{Q}$ will be lower than the low Tobin Q stocks.

To evaluate the gap between good stocks and good corporations, we collected the primary data for the benchmark enterprises that Commonwealth surveyed annually for Taiwan's domestic and foreign companies, to compare the returns of common stocks and the performances of these companies, to find whether the investors exhibit cognitive biases or not, and to try to explain this phenomenon from the perspective of behavioral finance.

The other framework of this paper is constructed as follows: Section 2 reviews the literature of behavioral finance, which relate to cognitive biases; Section 3 presents the data and methodology; the empirical results are listed in Section 4; and Section 5 concludes for this study.

\section{LITERATURE REVIEW}

Kahneman and Tversky (1973) present the beliefs of representativeness, a common cognitive bias on decision making. For the environments that subjects faced that are different than the status quo assumptions and the considerations they formed, psychological conflicts happened. Therefore, people will try to find a new approach to decrease the psychological conflicts for making decisions easily. This is Festinger's (1957) identification: people will ignore new information that may change the outcomes or debate their erroneous concepts to a standstill on the existing methods for problem solving. If the cognitive biases exist, the behavior that people use to make decisions or to solve problems will be the conservative or customary orientation, to decrease the psychological phenomenon of anger, regret, and fear, but most importantly, to shorten the process of choice. For making the financial decisions in the capital markets, investors 
will face highly complex and uncertain situations, thus, Kahneman and Riepe (1998) state that investors will preclude reliance on fixed rules and intuitions. In that way, intuitions play a crucial role in most decisions, but it is a major source of cognitive biases. Moreover, Kahneman and Riepe (1998) divide the cognitive biases into the following four categories: overconfidence, optimism, hindsight, and overreaction. For each category, the distortion of decision happened, while decreasing the quality of financial management.

In an efficient financial market, the most likely cognitive bias is the selection criteria for financial assets: investors who wish to maximize the returns of their portfolios will allocate the valuable financial assets into the portfolio under the proper weighting of mean-variance principle developed by Markowitz (1952). And, if the capital market is perfect, just like the assumptions that CAPM identified, the expected returns of the investors' portfolio will be decided by the risk-free interest rate, market portfolio returns, and the systematic risk, beta. That is, the higher the beta, the higher the expected return of the portfolio. The criteria to determine the expected returns for financial assets illustrated here is the so-called standard finance that Statman (1999) identified. On the other hand, Hirshleifer (2001) suggests the psychological factors are considered into the valuation model recently, therefore, the expected returns for financial assets are determined by the risks and misvaluations of investors perception.

Fama and French (1992) study the key factors which explain the volatility of financial assets and find the relationships between beta and stock returns is not statistically significant, but corporate size is negatively related and book-to-market ratio is positively related to stock returns. To explain the empirical results, Fama and French (1992) divide the theories into two contexts, one related to rational valuation, and the other related to overreaction. From the viewpoint of rational valuation, investors know the relationship between the fundamental value of companies and risk, which size and book-to-market are indicators of risk. The overreaction, described by DeBondt and Thaler (1985), is that investors overreact to recent stock returns; therefore, the stocks of "losers" become undervalued, and the stocks of "winners" become overvalued. After comparing the two theories, Fama and French (1992) lean toward the former one, but this kind of explanation faced various challenges. For example, Roll and Ross (1994) suggest the relationship between returns and beta might be weak if the benchmark portfolio is not mean-variance efficient.

Sherfin and Statman (1994) propose the behavior capital asset pricing model (BCAPM) to divide the investors into information traders and noise traders. The information traders know the relationships between characteristics of companies and the 
return distributions of the stocks of these companies. However, the noise traders make systematic errors while evaluating the relationship between the fundamentals of companies and the return distributions of these stocks. In other words, information traders locate their portfolio on the mean-variance efficient frontier, and noise traders do not. Followed by the analysis of Sherfin and Statman (1994), the reason noise traders choose the non-efficient portfolio is cognitive bias, which leads noise traders to the belief that good stocks are stocks of good companies.

Moreover, Barberis, Shleifer, and Vishny (1998, BSV) and Daniel, Hirshleifer, and Subramanyam (1998, DHS) developed the behavior model to explain how the judgement biases of investors make the stock prices volatile, which in some events causes overreactions, and underreactions to others. The foundation of the BSV model is built on cognitive psychology and identifies two judgment biases, called representativeness and conservatism. The former, attributed to Kahneman and Tversky (1982), propose that people give too much attention to recent events and too little weight to previous patterns. And the latter, proposed by Edwards (1968), identifies that people change slowly when new events happen, even if new evidence exists. In the BSV model, stock earnings are random walk processes, but investors falsely perceive that there are two earnings regimes. In regime A, which in the assumptions of investors is more likely, to mistakenly think the change of stock prices is likely to be temporary. In regime $\mathrm{B}$, which investors are less likely to think, fluctuations of stock prices make investors perceive the fundamentals of the corporations will change. If the regime A holds, the short-term volatility of stock prices is evidence of momentum (Jegadeesh and Titman, 1993), and regime B can explain the long-term return reversal described by DeBondt and Thaler (1985) and the contrarian investment strategies presented by Lakonishok et al. (1994). Since the anomalies of stock prices volatility are common in the capital market nowadays, Fama (1998) also suggests the empirical evidence of return reversal are equally likely as chance results. For more details, see Sherfin and Statman (2000) and Kothari et al. (2006).

The DHS model, in the other hand, divides the participants of capital markets into informed and uninformed investors, in which the uninformed investors are not subject to judgement biases and do not have the market power to determine the stock prices. The informed investors, though, can determine the stock prices, but subject to two judgement biases, overconfidence and self-attribution. Overconfidence makes the informed investors exaggerate the precision of the private information they have, and self-attribution leads them to decrease the weighting of public information when they make a decision. In capital markets, overconfidence induces much more transactions and decreases returns 
for individual investors (Barber and Odean (2000), Barber and Odean (2001), Barber and Odean (2002), Gervais and Odean (2001)). The cognitive errors for overreaction on private information and underreaction on public information tend to lead to the continuation of stock returns in the short-term, and reversal in the long-term. In summary, see Barberis and Thaler (2002) and Grinblatt and Han (2005).

For empirical studies, Filbeck (2001) investigates the differences for abnormal returns between the "good" corporations and "good" stocks. Followed by the Wall Street Journal survey, he selected 12 publicly traded firms which were mentioned as the better places to work and compared the stock returns with a matched group which was similar in the SIC code and capitalization. After the empirical work, he found the stock returns of the admirable corporations were not superior to the S\&P 500 and the matched sample in the period prior to, during, and following the release of the good places to work survey results. This evidence shows that corporations which pursue the goals of fair labor practices, progressive benefits, sound environmental practices, and satisfied employees may not maximize the wealth of shareholders. But investors cannot perceive the behavior of managers correctly, while mindful that the stock returns will reflect the fundamentals of securities; that is, the stocks of good corporations are good stocks. Therefore, investors choose the stocks of admirable corporations in their portfolio and expect the excess return that good stocks will have. But followed by the work of Filbeck (2001) for the sample period of 12 years, the empirical evidence cannot support the hypothesis that stocks of good corporations are good stocks. This finding means that investors' cognitive biases actually exist, and the performance of that portfolio is not higher than the counterpart corporations and market portfolio.

From the psychological aspects discussed above, cognitive biases are common phenomena that exist in the external behavior of investors. But the literatures have not provide the empirical evidences in capital markets to present the cognitive biases among various participants which have different characteristics, this is why the paper engages to analyze the differences between financial experts and investors. In the next section, we will try to develop the empirical framework to find evidences of cognitive biases of investors in Taiwan capital market.

\section{METHODOLOGY}

\section{Data}

Commonwealth, a well-known practitioner-orientated magazine focused on the business-related field in Taiwan, surveyed the admirable enterprises annually, called it a benchmark, to investigate the key success factors of these enterprises. In this survey, 
editors of Commonwealth designed a questionnaire, which included ten dimensions ${ }^{1}$, and scores from 1 to 10 for each dimension; the higher the score, the higher the acceptance and perceived level for that dimension. After getting the score for each dimension, they summarize it on the average weighting basis to present the final score. The sample firms of this survey are the Top 1000 business of Taiwan last year, including the domestic and foreign businesses and the listed and privately held corporations. The corporations that had a loss last year are excluded from the samples.

In 2004, Commonwealth issued 4656 questionnaires to survey the admirable corporations; entrepreneurs, managers, bankers, accountants, and financial analysts, were invited to answer this questionnaire. After the surveys time period ended, 1903 questionnaires were available, entrepreneurs and managers answered 1075, and 828 were by financial professionals. Due to the aims of the paper are focused on the cognitive biases between financial experts and investors, the responses of entrepreneurs and managers are excluded out of empirical study. Finally, the editors of Commonwealth computed the scores for each dimension and summarized the scores of ten items by average weighting to get the final score. The final score, which ranked by descending order, presented the benchmark profile of Taiwan in 2004.

The related secondary data for benchmark enterprises and other listed companies, for example, capitalization, stock prices volatility, and book value, are all collected from the Taiwan Stock Exchange Corporation (TSEC) Databank. In 2004, there were 697 listed companies in the TSEC. For the purpose of analyzing consistency, we deleted the stock price data for 28 newly listed companies, 10 de-listed companies, 25 trading regulation changed companies ${ }^{2}$, and 14 data missing companies. After this adjustment, the available data for listed companies in the research are 620.

\section{Method}

At first, we followed by Solt and Statman (1989) to present the description statistics of log of size, B/M, beta, book value, EPS, P/E, stock returns and volatility for the listed companies and benchmark enterprises, separately, to verify the hypothesis that:

\footnotetext{
1 The ten dimensions include business vision, product innovation, customer orientation, operation performance, financial capability, human resources, technology availability, international business scope, long term investment value, and enterprise civil responsibility. The last two items were added into the survey since 1997.

${ }^{2}$ Under the TSEC Listing Regulation, if the book value per share of listed companies is lower than half of the par value of common stock, the trading regulation for the companies should be changed. That is, prepaid the dollar amounts to securities dealers before buying, and prepaid the shares to securities dealers before selling.
} 
H1: The benchmark enterprises perform better both on financial sides and stock market than the other listed companies.

Secondly, we defined a multiple linear regression model to try to find the various explanatory variables for stock returns:

$$
\begin{aligned}
\text { stock returns }= & \alpha_{0}+\alpha_{1} \text { Log of Size }+\alpha_{2} \mathrm{~B} / \mathrm{M}+\alpha_{3} \beta+\alpha_{4} \text { Book Value } \\
& +\alpha_{5} \mathrm{EPS}+\alpha_{6} \mathrm{P} / \mathrm{E}+\varepsilon
\end{aligned}
$$

In the first step, regress the listed companies and benchmark enterprises separately, to find whether the independent variable(s) influence stock returns or not, and compare the variable(s) which influence the stock returns of listed companies and benchmark enterprises is (are) the same or not. In equation (1), we follow the suggestion proposed by Shefrin and Statman (1995), define the corporate size as logarithmic form, to try to smooth the difference between large and small size companies. On the other hand, B/M means book value divides by market value, and $\mathrm{P} / \mathrm{E}$ equals stock price divides by earnings per share, both similar to Book Value and EPS, to make these two independent variables looks like unnecessary in the model. But this is not the case. After the empirical work, we find the four independent variables show the inconsistent economic meanings, which indicate the cognitive biases existed, and this is the reason why we suggest holding the independent variables in equation (1). Finally, as the definition illustrated above, if a company has a loss this year, the $\mathrm{P} / \mathrm{E}$ will be negative, making the analysis of $\mathrm{P} / \mathrm{E}$ effect nonsense. Therefore, if the EPS of sample companies are negative, it will be excluded from the regression analysis. Moreover, due to the criteria for selecting good corporations based on the ten dimensions described above, which Shefrin and Statman (1995) define as quality of management, it is worthy to know whether the independent variables of equation (1) could explain the final score of the benchmark enterprises or not.

$$
\begin{aligned}
\text { final scores }= & \alpha_{0}+\alpha_{1} \log \text { of Size }+\alpha_{2} \mathrm{~B} / \mathrm{M}+\alpha_{3} \beta+\alpha_{4} \text { Book Value } \\
& +\alpha_{5} \mathrm{EPS}+\alpha_{6} \mathrm{P} / \mathrm{E}+\varepsilon
\end{aligned}
$$

For equation (2), the dependent variable is the ranking criteria of benchmark enterprises. If the independent variables are statistically significant to explain the final score, the financial indicators will be the key determinants to decide which corporations are benchmark enterprises. On the other hand, there are two dimensions, called financial 
capability and long term investment values, that are financially related items, but that lack the definitions in the Commonwealth survey. Therefore, we tried to replace the dependent variable of equation (2) as the two dimensions separately, to find the relationships between financial dimensions and indicators. Both equation (1) and (2) can help us to verify the second hypothesis for:

H2: If the cognitive biases existed, the key factors that determine the benchmark enterprises and influence the stock returns and quality of management will be different. For financial experts, the criteria are subjective on corporate size and image, for investors, the criteria are objective on stock returns.

Following the Commonwealth survey, the invited financial experts whose focus on the overall managerial aspects as the determinants of benchmark enterprises, and the criteria for good stocks that investors perceive in the capital market are returns; therefore, the question is whether the two variables are interrelated or not? In order to know the relationships, we defined two simple linear regression functions that use the final score and stock returns as dependent variable, separately, to know if management can explain stock returns, and vice versa. Equation (3) and (4) are the regression functions:

stock returns $=\alpha_{0}+\alpha_{1}$ quality of management

quality of management $=\alpha_{0}+\alpha_{1}$ stock returns

The purposes of equation (3) and (4) are engaged to examine the hypothesis that managerial capabilities and stock returns are the same or not:

H3: The perceptions for a good company and a good stock between financial experts and investors are not the same, to make the criteria of a benchmark enterprise are different than the determinants of a good stock.

In order to distinguish the performance differences in capital market among the group of market portfolio to benchmark portfolio, and the group of each industrial benchmark portfolio to the related industrial portfolio, we followed the index computation method of TSEC for analysis, to show: 


\section{$I N D E X=\frac{\sum P_{i t} Q_{i t}}{\sum P_{i 0} Q_{i t}}$}

where, $P_{i t}=$ the price for the $i^{\text {th }}$ common stock of sample corporation in the current date

$P_{i 0}=$ the price for the $i^{\text {th }}$ common stock of sample corporation in the base date

$Q_{i t}=$ the issued shares for the $i^{\text {th }}$ sample corporation in the current date

After the regression process to analyze the relationships for each variable, we used the non-parameter analysis technique to test the differences between the two paired samples for benchmark versus market portfolio, and industrial portfolio of benchmark versus related industries. Moreover, we divided the market portfolio into three categories by stock returns and tested to see whether the characteristics for the six financial indicators are really different among the three subsamples and benchmark samples. Also, this procedure of non-parameter analysis can help us to test the hypothesis of $\mathrm{H} 1, \mathrm{H} 2$, and H3.

\section{RESULTS}

In this section, we follow the method introduced in section 3 to find the empirical evidences to support or reject the hypotheses that the stocks of good corporations are good stocks or not.

\section{Description Statistics for Benchmark Enterprises and Listed Companies}

In Table 1, we illustrate the overall profile for the Top 100 benchmark enterprises of 2004. For the purposes of same final score, the number of benchmark enterprises is 102, a little more than 100. The amounts and percentage of benchmark for each industry are 46 (45.10\%) in manufacturing, 33 (32.35\%) in services and 23 (22.55\%) in finance, separately. 69 benchmark enterprises are domestic companies, with 48 listed in TSEC, 21 are privately held, and the other 33 benchmark enterprises are subsidiaries of multinational corporations.

The average scores for the overall Top 100 benchmark are 7.20, with manufacturing and financial sectors higher than the average and services sectors lower than the average. The standard deviations of the services sectors are more centered than the other two industry categories and the whole samples, to identify the characteristics for the services sectors to be standardized. Also, the skewness and kurtosis for the Top 100 benchmark samples are 1.05 and 0.93, separately (not reported here), which suggests that the sample distribution is not normalized and skew to the right, to verify that the benchmark enterprises will perform better than other corporations in the population 
Table 1 The Overall Profile of Top 100 Benchmark Enterprises on 2004

\begin{tabular}{|c|c|c|c|c|c|c|c|}
\hline \multirow[t]{2}{*}{$\begin{array}{l}\text { Industry } \\
\text { Category }\end{array}$} & \multirow[t]{2}{*}{ Sub-Industry } & \multirow[t]{2}{*}{ No. } & \multirow[t]{2}{*}{$\begin{array}{c}\text { Average } \\
\text { Score }\end{array}$} & \multirow[t]{2}{*}{$\begin{array}{c}\text { Standard } \\
\text { Deviation }\end{array}$} & \multicolumn{2}{|c|}{$\begin{array}{c}\text { Domestic } \\
\text { Companies }\end{array}$} & \multirow[t]{2}{*}{$\begin{array}{c}\text { Foreign } \\
\text { Companies }\end{array}$} \\
\hline & & & & & Listed & Private & \\
\hline \multirow[t]{11}{*}{ Manufacturing } & Food & 2 & 7.18 & 0.52 & 2 & 0 & 0 \\
\hline & Steel & 1 & 7.86 & & 1 & 0 & 0 \\
\hline & Semi-Conductor & 6 & 7.38 & 0.53 & 3 & 0 & 3 \\
\hline & Computer & 6 & 7.45 & 0.39 & 6 & 0 & 0 \\
\hline & Electronics & 2 & 6.89 & 0.18 & 1 & 1 & 0 \\
\hline & Plastics & 7 & 7.25 & 0.33 & 4 & 2 & 1 \\
\hline & Vehicle & 5 & 7.27 & 0.24 & 4 & 0 & 1 \\
\hline & Textile & 6 & 6.92 & 0.13 & 5 & 1 & 0 \\
\hline & IC and Software & 8 & 7.16 & 0.35 & 3 & 3 & 2 \\
\hline & TFT-LCD & 3 & 7.19 & 0.43 & 3 & 0 & 0 \\
\hline & Sub Total & 46 & 7.23 & 0.37 & 32 & 7 & 7 \\
\hline \multirow[t]{7}{*}{ Services } & Airline & 5 & 7.02 & 0.28 & 2 & 0 & 3 \\
\hline & Retail & 5 & 7.20 & 0.49 & 1 & 3 & 1 \\
\hline & $\begin{array}{l}\text { Tele- } \\
\text { Communication }\end{array}$ & 14 & 7.11 & 0.22 & 2 & 0 & 12 \\
\hline & IT Channel & 1 & 7.42 & & 1 & 0 & 0 \\
\hline & Hotel & 5 & 6.94 & 0.18 & 1 & 2 & 2 \\
\hline & Shipping & 3 & 7.29 & 0.19 & 3 & 0 & 0 \\
\hline & Sub Total & 33 & 7.11 & 0.28 & 10 & 5 & 18 \\
\hline \multirow[t]{7}{*}{ Financial } & Financial & & & & & & \\
\hline & Holding & 4 & 7.35 & 0.36 & 4 & 0 & 0 \\
\hline & Company & & & & & & \\
\hline & Life Insurance & 6 & 7.11 & 0.38 & 0 & 4 & 2 \\
\hline & Banking & 7 & 7.45 & 0.56 & 0 & 3 & 4 \\
\hline & Securities Firm & 6 & 7.15 & 0.14 & 2 & 2 & 2 \\
\hline & Sub Total & 23 & 7.27 & 0.41 & 6 & 9 & 8 \\
\hline Total & & 102 & 7.20 & 0.36 & 48 & 21 & 33 \\
\hline
\end{tabular}

In order to distinguish the stocks of benchmark enterprises as good stocks or not, we tried to compare the performance differences in the stock market between listed and benchmark companies. As Solt and Statman (1989) suggest, investors perceive that priceearnings ratio and book-to-market ratio are indicators of a growth stock, and a growth stock means a good corporation. That is, a stock with a higher price-earnings ratio and a lower book-to-market ratio will make better returns. If the hypotheses are supported, the stocks of benchmark enterprises will be the good stocks. Table 2 shows the empirical results.

In Table 2, we divide the sample into five categories: TSEC listed companies, High, 
Middle, and Low stock returns listed companies, and Commonwealth benchmark enterprises, to compare the differences of the financial characteristics for six dimensions described by size, book-to-market ratio, beta, book value, EPS, and P/E ratio. Moreover, we present the description statistics of stock return and volatility, which can be seen as a proxy of capital market performance. For the corporate financial dimensions, the benchmark enterprises have higher size, book value, and EPS relative to the other four categories, and lower book-to-market ratio, beta, and P/E relative to the other four categories. This finding is consistent with Shefrin and Statman (1995) that investors perceive that good companies are large and have a low book-to-market ratio, which also support $\mathrm{H} 1$ that benchmark enterprises perform better on financial indicators. In order to verify whether the stocks of good companies perform better than the stocks of other listed companies or not, the description data of stock returns and volatility are also shown on Table 2. For stock returns, the benchmark enterprises are higher than the market portfolio but lower than the matched sample of high return companies, and the stock prices volatility of benchmark enterprises are more stable than the other samples. This empirical results, identify the stocks of benchmark enterprises do not outperform than the other stocks in capital market, but fluctuate steady, which contradict H1 to some extent.

Table 2 The Description Statistics of Listed Companies and Benchmark Enterprises on Size, $\mathrm{B} / \mathrm{M}$ ratio, Beta, Book Value, Return, and Volatility

\begin{tabular}{|c|c|c|c|c|c|c|c|c|}
\hline \multirow[t]{3}{*}{ Panel A } & \multicolumn{8}{|c|}{ TSEC Listed Companies } \\
\hline & \multicolumn{6}{|c|}{$\begin{array}{l}\text { The financial performance } \\
\text { indicator }\end{array}$} & \multicolumn{2}{|c|}{$\begin{array}{c}\text { The stock performance } \\
\text { indicator }\end{array}$} \\
\hline & $\log _{\text {of Size }}{ }^{\mathrm{a}}$ & B/M Ratio & Beta & $\begin{array}{l}\text { Book } \\
\text { Value }^{\text {b }}\end{array}$ & EPS & $\mathrm{P} / \mathrm{E}^{\mathrm{C}}$ & Return & Volatility \\
\hline Average & 14.930 & 0.952 & 1.252 & 14.854 & 1.525 & 22.982 & -0.004 & 0.103 \\
\hline Std Dv. & 1.187 & 0.462 & 0.792 & 5.907 & 2.672 & 68.944 & 0.033 & 0.080 \\
\hline Skewness & 0.903 & 1.005 & 6.425 & 1.934 & 0.687 & 12.086 & 0.098 & 11.825 \\
\hline Kurtosis & 0.500 & 1.498 & 90.548 & 8.046 & 5.671 & 179.992 & 0.356 & 215.853 \\
\hline Number & 620 & 620 & 620 & 620 & 620 & 498 & 620 & 620 \\
\hline \multirow[t]{3}{*}{ Panel B } & \multicolumn{8}{|c|}{ TSEC High Return Listed Companies } \\
\hline & \multicolumn{6}{|c|}{$\begin{array}{c}\text { The financial performance } \\
\text { indicator }\end{array}$} & \multicolumn{2}{|c|}{$\begin{array}{c}\text { The stock performance } \\
\text { indicator }\end{array}$} \\
\hline & Log of Size & B/M Ratio & Beta & $\begin{array}{l}\text { Book } \\
\text { Value }\end{array}$ & EPS & $\mathrm{P} / \mathrm{E}$ & Return & Volatility \\
\hline Average & 15.201 & 0.925 & 1.624 & 14.230 & 1.525 & 31.063 & 0.031 & 0.135 \\
\hline Std Dv. & 0.142 & 0.447 & 1.132 & 5.303 & 2.672 & 107.041 & 0.002 & 0.142 \\
\hline Skewness & 8.652 & 1.388 & 5.683 & 5.683 & 0.687 & 8.643 & 1.404 & 0.601 \\
\hline Kurtosis & 100.779 & 3.867 & 56.574 & 56.574 & 5.671 & 84.619 & 1.736 & -0.087 \\
\hline Number & 207 & 207 & 207 & 207 & 207 & 176 & 207 & 207 \\
\hline
\end{tabular}


Table 2 The Description Statistics of Listed Companies and Benchmark Enterprises on Size, $\mathrm{B} / \mathrm{M}$ ratio, Beta, Book Value, Return, and Volatility (Continued)

\begin{tabular}{ccccccccc}
\hline Panel C & \multicolumn{9}{c}{ TSEC Middle Return Listed Companies } \\
& \multicolumn{9}{c}{$\begin{array}{c}\text { The financial performance } \\
\text { indicator }\end{array}$} & & \multicolumn{2}{c}{$\begin{array}{c}\text { The stock performance } \\
\text { indicator }\end{array}$} \\
\hline & Log of Size & B/M Ratio & Beta & Book & EPS & P/E & Return & Volatility \\
Average & 15.026 & 0.930 & 1.076 & 14.979 & 1.807 & 17.425 & -0.005 & 0.085 \\
Std Dv. & 0.240 & 0.461 & 0.489 & 5.296 & 2.491 & 29.389 & 0.008 & 0.035 \\
Skewness & 0.829 & 0.744 & 0.388 & 1.313 & -0.148 & 6.968 & -0.017 & 0.956 \\
Kurtosis & 0.161 & 0.036 & -0.420 & 2.811 & 5.350 & 56.791 & -1.232 & 1.759 \\
Number & 207 & 207 & 207 & 207 & 207 & 174 & 207 & 207 \\
& & & & & & & &
\end{tabular}

\begin{tabular}{|c|c|c|c|c|c|c|c|c|}
\hline \multirow[t]{3}{*}{ Panel D } & \multicolumn{8}{|c|}{ TSEC Low Return Listed Companies } \\
\hline & \multicolumn{6}{|c|}{$\begin{array}{l}\text { The financial performance } \\
\text { indicator }\end{array}$} & \multicolumn{2}{|c|}{$\begin{array}{c}\text { The stock performance } \\
\text { indicator }\end{array}$} \\
\hline & Size & B/M Ratio & Beta & $\begin{array}{l}\text { Book } \\
\text { Value }\end{array}$ & EPS & $\mathrm{P} / \mathrm{E}$ & Return & Volatility \\
\hline Average & 14.562 & 1.002 & 1.051 & 15.354 & 1.161 & 19.906 & -0.040 & 0.088 \\
\hline Std Dv. & 1.087 & 0.476 & 0.379 & 6.946 & 3.101 & 35.909 & 0.016 & 0.030 \\
\hline Skewness & 1.501 & 0.931 & 0.266 & 2.143 & 0.952 & 7.736 & -1.122 & 1.165 \\
\hline Kurtosis & 2.988 & 1.072 & -0.201 & 9.086 & 5.915 & 72.757 & 1.051 & 2.620 \\
\hline Number & 206 & 206 & 206 & 206 & 206 & 148 & 206 & 206 \\
\hline \multirow[t]{3}{*}{ Panel E } & \multicolumn{8}{|c|}{ Commonwealth Benchmark Enterprises } \\
\hline & \multicolumn{6}{|c|}{$\begin{array}{c}\text { The financial performance } \\
\text { indicator }\end{array}$} & \multicolumn{2}{|c|}{$\begin{array}{l}\text { The stock performance } \\
\text { indicator }\end{array}$} \\
\hline & Log of Size & B/M Ratio & Beta & $\begin{array}{l}\text { Book } \\
\text { Value }\end{array}$ & EPS & $\mathrm{P} / \mathrm{E}$ & Return & Volatility \\
\hline Average & 16.752 & 0.542 & 0.944 & 21.786 & 4.310 & 13.407 & -0.001 & 0.072 \\
\hline Std Dv. & 1.267 & 0.189 & 0.436 & 9.021 & 3.251 & 8.112 & 0.020 & 0.029 \\
\hline Skewness & -0.467 & 0.291 & 0.234 & 1.892 & 2.279 & 3.552 & -0.024 & 0.758 \\
\hline Kurtosis & -0.269 & -0.761 & -0.892 & 4.671 & 7.784 & 15.407 & -0.178 & 0.170 \\
\hline Number & 48 & 48 & 48 & 48 & 48 & 48 & 48 & 48 \\
\hline
\end{tabular}

a. The capitalization is presented by logarithmic form of \$1,000 NT Dollar unit on the end of 2004 .

b. The net book value is presented by per share basis on the end of 2004 .

c. For the samples which $\mathrm{P} / \mathrm{E} \leqq 0$ are excluded.

\section{The Key Factors Which Influence the Stock Returns and Quality of Management}

Following Shefrin and Statman (1995), we regressed the stock returns of listed companies, high, middle, and low stock return listed companies, and benchmark enterprises on the daily data basis, to find what the key factor(s) to influence stock 
returns. In the model, we suggest log of size, book-to-market ratio, beta, book value, EPS, and P/E to be explanatory variables, which are consistent with, but extend to Shefrin and Statman (1995). For model 1, the sample is listed companies; and the samples of high, middle, and low stock returns listed companies and benchmark enterprises are attributed to Models 2 to 5 . Table 3 is the empirical results for the multiple linear regression models.

For Model 1, the coefficients of log of size, beta, book value, and EPS are all statistically significant at 99\% level and support size, beta, and EPS as positively related and book value as negatively related to stock returns of listed companies. In Model 2, beta is positive related and book value is negatively related to stock returns at the $99 \%$ significant level. In Model 3, size and book-to-market ratio both are positively related to stock returns at the 99\% significant level. And in Model 4, both size and EPS are positively related to stock returns at the $90 \%$ significant level, but beta is negatively related to stock returns at the 95\% significant level. For the empirical results of Models 1 to 4, the factors that influence stock returns are different, indicating anomalies exist. Because the sample firms of Models 2, 3, and 4 all are selected from Model 1 by return, the independent variables that influence Models 1 to 4 will be the same, but, actually, are not, to indicate the contradictory evidence among these samples.

In Model 5, the dependent variable is stock returns of benchmark enterprises, but all the dependent variables are not statistically significant. Even the F statistic is not statistically significant, to indicate that the multiple regression model cannot explain the stock price volatility. It is also an anomaly because the samples of benchmark enterprises are selected from all the listed companies. The question is again why the variables used to explain the stock returns of listed companies could not explain the benchmark enterprises? 
Table 3 The Multiple Linear Regression Analysis Results for Stock Returns

\begin{tabular}{|c|c|c|c|c|c|c|c|c|}
\hline Item & Model $1^{\mathrm{a}}$ & Model 2 & Model 3 & Model 4 & Model 5 & Model $6^{\mathrm{b}}$ & Model 7 & Model 8 \\
\hline $\begin{array}{c}\text { Inter- } \\
\text { cept }\end{array}$ & $\begin{array}{c}- \\
4.554^{* * *} \mathrm{c} \\
(0.000)^{\mathrm{d}}\end{array}$ & $\begin{array}{c}2.967 * * * \\
(0.003)\end{array}$ & $\begin{array}{c}- \\
4.784^{* * *} \\
(0.000)\end{array}$ & $\begin{array}{c}- \\
3.636 * * * \\
(0.000)\end{array}$ & $\begin{array}{c}0.678 \\
(0.501)\end{array}$ & $\begin{array}{c}6.167^{* * *} \\
(0.000)\end{array}$ & $\begin{array}{c}3.722 * * * \\
(0.001)\end{array}$ & $\begin{array}{c}4.201^{* * *} \\
(0.000)\end{array}$ \\
\hline $\begin{array}{l}\text { Log of } \\
\text { Size }\end{array}$ & $(0.000)$ & $\begin{array}{l}-0.877 \\
(0.382)\end{array}$ & $\begin{array}{c}3.724 * * * \\
(0.000)\end{array}$ & $\begin{array}{l}1.950^{*} \\
(0.053)\end{array}$ & $\begin{array}{l}-0.300 \\
(0.766)\end{array}$ & $\begin{array}{c}3.674 * * * \\
(0.001)\end{array}$ & $\begin{array}{c}5.861^{* * *} \\
(0.000)\end{array}$ & $\begin{array}{c}3.677^{* * *} \\
(0.001)\end{array}$ \\
\hline $\begin{array}{c}\mathrm{B} / \mathrm{M} \\
\text { Ratio }\end{array}$ & $\begin{array}{c}-0.329 \\
(0.742)\end{array}$ & $\begin{array}{l}-1.360 \\
(0.176)\end{array}$ & $\begin{array}{c}3.000 * * * \\
(0.003)\end{array}$ & $\begin{array}{c}0.556 \\
(0.579)\end{array}$ & $\begin{array}{l}-0.141 \\
(0.888)\end{array}$ & $\begin{array}{l}-1.365 \\
(0.180)\end{array}$ & $\begin{array}{l}-0.539 \\
(0.593)\end{array}$ & $\begin{array}{l}-1.646 \\
(0.108)\end{array}$ \\
\hline Beta & $\begin{array}{c}7.093 * * * \\
(0.000)\end{array}$ & $\begin{array}{c}3.828 * * * \\
(0.000)\end{array}$ & $\begin{array}{c}0.117 \\
(0.907)\end{array}$ & $\begin{array}{c}-2.408^{* *} \\
(0.017)\end{array}$ & $\begin{array}{c}0.123 \\
(0.903)\end{array}$ & $\begin{array}{c}-0.611 \\
(0.545)\end{array}$ & $\begin{array}{l}-1.145 \\
(0.259)\end{array}$ & $\begin{array}{l}-0.534 \\
(0.596)\end{array}$ \\
\hline $\begin{array}{l}\text { Book } \\
\text { Value }\end{array}$ & $\begin{array}{c}- \\
5.208^{* * *} \\
(0.000)\end{array}$ & $\begin{array}{c}- \\
2.760 * * * \\
(0.006)\end{array}$ & $\begin{array}{l}-0.832 \\
(0.406)\end{array}$ & $\begin{array}{l}-0.813 \\
(0.418)\end{array}$ & $\begin{array}{l}-0.476 \\
(0.637)\end{array}$ & $\begin{array}{l}1 . \\
(0 .\end{array}$ & $\begin{array}{l}0 . \\
(0 .\end{array}$ & $\begin{array}{c}0.354 \\
(0.725)\end{array}$ \\
\hline EPS & $\begin{array}{c}3.079 * * * \\
(0.002)\end{array}$ & $\begin{array}{c}0.981 \\
(0.328)\end{array}$ & $\begin{array}{c}1.580 \\
(0.116)\end{array}$ & $\begin{array}{l}1.836^{*} \\
(0.068)\end{array}$ & $\begin{array}{l}-0.262 \\
(0.794)\end{array}$ & $\begin{array}{l}-0 . \\
(0 .\end{array}$ & $\begin{array}{c}0.752 \\
(0.456)\end{array}$ & $\begin{array}{c}0.387 \\
(0.701)\end{array}$ \\
\hline $\mathrm{P} / \mathrm{E}$ & $\begin{array}{c}1.596 \\
(0.111)\end{array}$ & $\begin{array}{c}1.459 \\
(0.138)\end{array}$ & $\begin{array}{l}-1.011 \\
(0.314)\end{array}$ & $\begin{array}{c}0.613 \\
(0.541)\end{array}$ & $\begin{array}{l}-1.455 \\
(0.153)\end{array}$ & $\begin{array}{c}-0.231 \\
(0.818)\end{array}$ & $\begin{array}{c}0.771 \\
(0.445)\end{array}$ & $\begin{array}{l}-0.263 \\
(0.794)\end{array}$ \\
\hline $\mathrm{F}$ & $\begin{array}{c}20.694 * * * \\
(0.000)\end{array}$ & $\begin{array}{c}5.674^{* * *} \\
(0.000)\end{array}$ & $\begin{array}{c}3.535^{* * *} \\
(0.000)\end{array}$ & $\begin{array}{c}2.333^{* *} \\
(0.035)\end{array}$ & $\begin{array}{c}0.595 \\
(0.732)\end{array}$ & $\begin{array}{c}3.628 * * * \\
(0.006)\end{array}$ & $\begin{array}{c}6.942^{* * *} \\
(0.000)\end{array}$ & $\begin{array}{c}4.624^{* * *} \\
(0.001)\end{array}$ \\
\hline Adj $R^{2}$ & 0.193 & 0.138 & 0.081 & 0.052 & -0.054 & 0.251 & 0.431 & 0.316 \\
\hline $\mathrm{N}$ & 495 & 176 & 173 & 146 & 48 & 48 & 48 & 48 \\
\hline \multicolumn{9}{|c|}{$\begin{array}{l}\text { a. TSEC Listed Companies for Model 1, High, Middle, and Low Stock Return Listed Companies for } \\
\text { Model } 2,3 \text {, and } 4 \text {, separately, and Commonwealth Benchmark Enterprises for Model } 5 \text {. The } \\
\text { dependent variable is stock returns. } \\
\text { b. The dependent variables for Model } 6 \text { to } 8 \text { are the total score, the score of financial capability, and the } \\
\text { score of long term investment value, separately. } \\
\text { c. The } t \text { value, for } * * * \text { significant at } 99 \% \text { level, }{ }^{* *} \text { significant at } 95 \% \text { level, and * significant at } 90 \% \\
\text { level. } \\
\text { d. The } p \text { value. }\end{array}$} \\
\hline
\end{tabular}

Recall the selection criteria of benchmark enterprises where the ranking is average weighting score for ten dimensions. Shefrin and Statman (1995) call it quality of management, which is not related to capital markets directly, except for the financial 
capability and long-term investment value. Therefore, the stocks of benchmark enterprises may not be the best financial assets in the capital market. The results of Model 5 , that each independent variable is not statistically significant, would be the evidences to explain why the financial indicators cannot influence the stock returns. Moreover, there is only one benchmark enterprise (not reported here) located in the Top 48 high stock returns sample to prove the cognitive errors which existed between the investors and the financial experts. Although the financial indicators cannot explain the stock returns, if replace the dependent variable as the scores of benchmark enterprises, are the financial indicators still the efficient explanatory factors?

To verify this viewpoint, we rewrote the multiple linear regression models, which change the dependent variables for the total scores, the scores of financial capability, and the scores of long-term investment value. The empirical results are reported on Models 6 to 8 of Table 3. In all the three models, only intercept and log of size are statistically significant at $99 \%$ level; the other dependent variables are not statistically significant even at $90 \%$ level. The empirical results show the good corporation criteria for financial experts is capitalization, and the larger a corporation, the higher is the possibility the corporation is a benchmark enterprise. The other financial indicators are not key factors to decide the final scores, financial capability, and long-term investment value for a benchmark enterprise. For the differences of empirical results, we can conclude that the evaluation of the Commonwealth survey for benchmark enterprises are a subjective identification of financial experts, in which capitalization influences the final ranking; and that the evaluations of investors for good stocks are objective, focused on returns. That is, the cognitive biases really exist within the group of investors and financial experts, which support $\mathrm{H} 2$ listed above.

\section{The Relationships between Stock Returns and Quality of Management}

In this subsection, we focus on the relationships between stock returns and quality of management, to find the dimensions that determine the quality of management are also the determinants influencing stock returns. At first, we use the stock returns as dependent variable, and the quality of management as independent variable, to run a simple regression model. The empirical results are reported on Model 1 of Table 4. Secondly, we change the quality of management as dependent variable, and the stock returns as independent variable, and run a simple regression again. Model 2 of Table 4 shows the empirical results. In these two models, the dependent variable is not statistically significant, indicating quality of management cannot explain the volatility of stock returns, and stock returns also do not have the explanatory power to determine which one 
is a benchmark enterprise.

In Model 3, we set the ten dimensions that financial experts use to evaluate the benchmark enterprises as independent variables, and stock returns as dependent variable, to find whether the dimensions are determinants to influence the stock returns. As the empirical results show on Table 4, there are three dimensions meet the statistically significant criteria, for technology availability statistically significant at 95\% level, and international business scope and long-term investment value statistically significant at $90 \%$ level. But the coefficients of technology availability and international business scope are negative, indicating these two dimensions are negatively related to stock returns, which means the corporations that have narrower business scopes and lack of technology will make higher stock returns.

For the models of Table 4, the first two models present the quality of management and the stock returns as irrelevant, indicating that the stocks of good corporations and good stocks are not the same. The regression results of Model 3 make no sense, showing that the criteria of a benchmark enterprise are different than the determinants of a good stock, which consistent with H3.

\section{Stock Performance between Benchmark Enterprises, Industry Portfolio, and Market Portfolio}

After the discussions described above, we found that the determinants between good stocks and good corporations are different. In this subsection, we will try to identify the phenomenon of bounded rationality (Simon, 1955). If the investors are fully rational, and the capital market is efficient, the portfolios, which consist of the benchmark enterprises, will perform better than the matched market or industry portfolio. Therefore, if the hypothesis that stocks of good performance corporations would be better targets for investing, the average stock returns will be statistically significantly higher than the other categories.

To test this hypothesis, we calculated the benchmark portfolio index using the same method as TSEC to compare the differences of stock returns between the benchmark portfolio and the market portfolio. Secondly, we separated the stocks of benchmark enterprises into the individual industry categories followed by the first two digits of the TSEC securities code ${ }^{3}$, and calculated the industrial portfolio index of the benchmark enterprises to compare with the TSEC industrial index. All the paired samples are tested by the Wilcoxon sign test, and the empirical results are reported in Table 5.

\footnotetext{
${ }^{3}$ For each listed security, TSEC designs a four digit securities code, the first two is the industry category for the corporations, and the industry identification is defined by TSEC.
} 
Table 4 The Linear Regression Analysis Results for Stock Returns and Quality of Management

\begin{tabular}{|c|c|c|c|}
\hline Item & Model $1^{\mathrm{a}}$ & Model 2 & Model 3 \\
\hline Intercept & $\begin{array}{l}-0.121 \\
(0.904)\end{array}$ & $\begin{array}{c}131.697 * * * \mathrm{~b} \\
(0.000)\end{array}$ & $\begin{array}{c}0.735 \\
(0.467)\end{array}$ \\
\hline Quality of Management & $\begin{array}{c}0.117 \\
(0.907)\end{array}$ & & \\
\hline Stock Returns & & $\begin{array}{c}0.117 \\
(0.907)\end{array}$ & \\
\hline Business Vision & & & $\begin{array}{c}0.517 \\
(0.608)\end{array}$ \\
\hline Product Innovation & & & $\begin{array}{c}0.176 \\
(0.861)\end{array}$ \\
\hline Customer Orientation & & & $\begin{array}{c}1.256 \\
(0.217)\end{array}$ \\
\hline Operation Performance & & & $\begin{array}{l}-1.483 \\
(0.147)\end{array}$ \\
\hline Financial Capability & & & $\begin{array}{c}0.344 \\
(0.733)\end{array}$ \\
\hline Human Resource & & & $\begin{array}{c}0.052 \\
(0.959)\end{array}$ \\
\hline Technology Availability & & & $\begin{array}{c}-2.112 * * \\
(0.041)\end{array}$ \\
\hline International Business Scope & & & $\begin{array}{l}-1.687^{*} \\
(0.100)\end{array}$ \\
\hline Long Term Investment Value & & & $\begin{array}{l}1.933^{*} \\
(0.061)\end{array}$ \\
\hline Enterprise Civil Responsibility & & & $\begin{array}{l}-0.218 \\
(0.829)\end{array}$ \\
\hline $\mathrm{F}$ & 0.014 & 0.014 & 2.071 \\
\hline Adj. $R^{2}$ & -0.021 & -0.021 & 0.186 \\
\hline $\mathrm{N}$ & 48 & 48 & 48 \\
\hline
\end{tabular}

a. For Model 1, the independent variable is the quality of management, and the dependent variable is the stock returns. For Model 2, the independent variable is the stock returns, and dependent variable is the quality of management. For Model 3, the independent variables are the ten dimensions to decide which one is benchmark enterprise, and the dependent variable is also stock returns.

b. ${ }^{* * *}$ indicates statistically significant at $99 \%$ level, $* *$ indicates statistically significant at $95 \%$ level, and * indicates statistically significant at $90 \%$ level. 
Table 5 The Wilcoxon Z Test of Paired Sample for Each Industry Categories and Market Portfolio

\begin{tabular}{|c|c|c|c|c|c|}
\hline \multirow[t]{2}{*}{ Item } & \multicolumn{4}{|c|}{ Average Weighted Stock Returns (\%) } & \multirow[t]{2}{*}{ Number } \\
\hline & Market & Industry $^{\mathrm{a}}$ & Benchmark $^{\mathrm{b}}$ & Wilcoxon Z & \\
\hline Market Portfolio & 0.028 & & 0.001 & -1.363 & 48 \\
\hline Food & & 7.864 & 0.103 & -0.376 & 1 \\
\hline Plastics & & 4.292 & 3.016 & -0.864 & 4 \\
\hline Textile & & 9.576 & 12.380 & -0.797 & 5 \\
\hline Steel & & 12.990 & 11.140 & -0.712 & 1 \\
\hline Vehicle & & -6.280 & -0.960 & -0.067 & 4 \\
\hline Electronics & & -1.468 & -4.204 & -0.523 & 19 \\
\hline Transportation & & 9.768 & 4.940 & -1.577 & 5 \\
\hline Hotel & & 12.990 & 4.276 & -0.368 & 2 \\
\hline Finance & & 8.908 & 7.576 & -0.051 & 6 \\
\hline Retail & & 5.080 & 1.484 & -0.926 & 1 \\
\hline
\end{tabular}

a. The industrial portfolio, which listed by industrial categories.

b. The simulated industrial portfolio, which combined with the benchmark enterprises in the same industry.

In this table, all the groups that compare by the average stock returns are not statistically significant, which means that the returns of the benchmark enterprises portfolio do not perform better than the market portfolio, and in each industry category, the same results exist. Therefore, the empirical results suggest that the stock performance of the benchmark enterprises is not superior to other listed stocks. The criteria for selecting a stock in the capital market by investors are not the same as those used in selecting a good corporation by financial experts, which consistent with H2. 
Table 6 The Mann-Whitney Test for Benchmark Enterprises and Paired Sample

\begin{tabular}{|c|c|c|c|c|c|}
\hline$\overline{\text { Category }}$ & Item & Market & $\begin{array}{l}\text { High Return } \\
\text { Group }^{\mathrm{a}}\end{array}$ & $\begin{array}{l}\text { Middle Return } \\
\text { Group }\end{array}$ & $\begin{array}{l}\text { Low Return } \\
\text { Group }\end{array}$ \\
\hline \multirow[t]{6}{*}{$\begin{array}{l}\text { Financial } \\
\text { Indicator }\end{array}$} & Log of Size & $\begin{array}{c}-8.620 * * *^{b} \\
(0.000)^{c}\end{array}$ & $\begin{array}{c}-3.640^{* * *} \\
(0.000)\end{array}$ & $\begin{array}{c}-6.888^{* * *} \\
(0.000)\end{array}$ & $\begin{array}{c}-3.747 * * * \\
(0.000)\end{array}$ \\
\hline & B/M Ratio & $\begin{array}{c}-7.344^{* * * *} \\
(0.000)\end{array}$ & $\begin{array}{c}-2.841^{* * *} \\
(0.004)\end{array}$ & $\begin{array}{c}-5.594 * * * \\
(0.000)\end{array}$ & $\begin{array}{c}-3.584 * * * \\
(0.000)\end{array}$ \\
\hline & Beta & $\begin{array}{c}-3.329 * * * \\
(0.001)\end{array}$ & $\begin{array}{c}-2.454^{* *} \\
(0.014)\end{array}$ & $\begin{array}{c}-2.718^{* * * *} \\
(0.007)\end{array}$ & $\begin{array}{l}-0.110 \\
(0.912)\end{array}$ \\
\hline & Book Value & $\begin{array}{c}-6.992 * * * \\
(0.000)\end{array}$ & $\begin{array}{c}-3.164^{* * *} \\
(0.002)\end{array}$ & $\begin{array}{c}-5.984 * * * \\
(0.000)\end{array}$ & $\begin{array}{c}-2.627 * * * \\
(0.009)\end{array}$ \\
\hline & EPS & $\begin{array}{c}-7.208^{* * *} \\
(0.000)\end{array}$ & $\begin{array}{c}-2.604^{* * *} \\
(0.009)\end{array}$ & $\begin{array}{c}-6.025^{* * * *} \\
(0.000)\end{array}$ & $\begin{array}{c}-3.282 * * * \\
(0.001)\end{array}$ \\
\hline & $\mathrm{P} / \mathrm{E}$ & $\begin{array}{l}-0.247 \\
(0.805)\end{array}$ & $\begin{array}{l}-0.552 \\
(0.581)\end{array}$ & $\begin{array}{l}-1.274 \\
(0.203)\end{array}$ & $\begin{array}{l}-0.695 \\
(0.487)\end{array}$ \\
\hline \multirow[t]{2}{*}{$\begin{array}{l}\text { Capital Market } \\
\text { Performance }\end{array}$} & Stock Returns & $\begin{array}{l}-1.050 \\
(0.294)\end{array}$ & $\begin{array}{l}-1.229 \\
(0.219)\end{array}$ & $\begin{array}{l}-1.798 * \\
(0.072)\end{array}$ & $\begin{array}{c}-2.181^{* *} \\
(0.029)\end{array}$ \\
\hline & Volatility & $\begin{array}{c}-4.614^{* * *} \\
(0.000)\end{array}$ & $\begin{array}{c}-3.539 * * * \\
(0.000)\end{array}$ & $\begin{array}{c}-2.970 * * * \\
(0.003)\end{array}$ & $\begin{array}{l}-0.723 \\
(0.469)\end{array}$ \\
\hline
\end{tabular}

a. The numbers of high, middle, and low return groups are 207, 207, and 206, separately. And the numbers of benchmark enterprises, which included in the groups, are 13, 25, and 10, separately.

b. The value is $\mathrm{Z}$ statistic, and $* * *$ indicating statistically significant at $99 \%$ level, ** indicating statistically significant at $95 \%$ level, and * indicating statistically significant at $90 \%$ level.

c. The one-tail $p$ value.

\section{The Comparison among the Profile of Benchmark Enterprises and Paired Samples}

Finally, we divided the listed companies into three categories depending on the stock returns, named high, middle, and low return groups, to compare the differences among the six financial indicators and the two capital market performance indices, with the benchmark enterprises, separately.

Table 6 shows the empirical results of the Mann-Whitney test. For the financial indicators, except $\mathrm{P} / \mathrm{E}$, the $\mathrm{Z}$ statistics all are negative, and statistically significant at $99 \%$ level (beta for low return group is not statistically significant), which describes the profile of the benchmark enterprises as having larger capitalization, higher book-to-market ratio, 
beta, book value, and EPS. This phenomenon indicates the benchmark enterprises are the corporations that perform better than the paired samples on the financial side. If the capital market is efficient, and investors are informed, the stocks of the benchmark enterprises will be better choices for investors due to the excellent performance on financial indicators. Therefore, the stock returns for the benchmark enterprises will be higher than the paired samples, and the volatility will be more stable. If the hypothesis exists, the $Z$ statistic of stock returns will be negative and statistically significant, and the $\mathrm{Z}$ statistic of stock volatility will be statistically insignificant. In Table 6, the empirical results of last two rows violate the hypothesis H1, indicating the performances of the benchmark stocks are not superior to the other paired samples. The evidence here suggests the anomalies and inconsistency between the good corporations and good stocks, which supports the phenomenon of bounded rationality (Simon, 1955) and cognitive biases (Kahneman and Tversky, 1973, 1979).

\section{CONCLUSIONS}

This paper contributes to the empirical study for the hypothesis of whether the good stocks are the stocks of good corporations or not. Based upon the concepts of behavioral finance that the capital market is a highly complex environment, investors will center on the fixed rules as adapted and their intuitions to make decisions. This is the situation of cognitive biases that Kahneman and Riepe (1998) identified. If cognitive biases exist, the behavior of capital market participants may not be fully rational in making decisions on portfolios not located on the mean-variance frontier, and to make systematic errors between the fundamentals and stock returns of these corporations. Therefore, Sherfin and Statman (1994) propose the BCAPM model, to divide investors into information and noise traders, to try to explain the biases. Moreover, Barberis, Shleifer, and Vishny (1998), and Daniel, Hirshleifer, and Subramanyam (1998) developed the behavior model to explain how the judgement biases make the stock prices volatile.

Under the theories of behavioral finance described above, we analyzed the capital market performance differences between the good corporations and other listed corporations of TSEC to find the evidence to explain whether stocks of good corporations are really good stocks or not. Followed by the survey results of the Commonwealth, we choose the 48 listed companies of TSEC from the Top 100, defined as benchmark enterprises, and compared with other TSEC listed companies, to find the differences of these two samples. The empirical results suggest the characteristics of the benchmark enterprises include larger size, better financial indicators of book-to-market ratio, beta, book value, and EPS, relative to other listed companies, but the performances of the stocks are not superior to other listed stocks. Therefore, we can conclude that the findings 
show that the phenomena for good stocks are different than the stock of good corporations. Since the financial experts have low cognitive biases and professional capabilities, the benchmark enterprises they selected should perform better in the capital market based on intuition, but, actually, they do not. Therefore, judgement biases exist even with the financial experts, indicating that the dimensions to decide on the good corporations and the criteria to decide on the good stocks are different.

This paper is a cross-sectional based research because of the data for benchmark enterprises are not consistent per year. Therefore, we can not analyze the cognitive biases between financial experts and investors, and also can not compare the differences among the categories of industry for benchmark enterprises on the time-series basis. All the restrictions illustrated here limit the generalizations of explanations for this paper.

For further studies, we suggest that researchers extend the model into international perspectives to compare the differences among various capital markets and to distinguish if the degrees of cognitive biases and capital market anomalies are influenced by cultural factors or not, which proposed by Grinblatt and Keloharju (2001). Also, distinguish the differences of cognitive biases on time-series basis is a possible direction for future studies.

\section{REFERENCES}

Barber, B., \& Odean, T. 2000. Trading is hazardous to your wealth: the common stock performance of individual investors. Journal of Finance, 55. 773-806.

Barber, B., \& Odean, T. 2001. Boys will be boys: gender, overconfidence, and common stock investment. Quarterly Journal of Economics, 141. 261-292.

Barber, B., \& Odean, T. 2002. On line investors: do the slow die first? Review of Financial Studies, 15. 455-487.

Barberis, N., \& Thaler, R. 2002. A survey of behavioral finance. NBER working paper.

Barberis, N., Shleifer, A., \& Vishny, R. 1998. A model of investor sentiment. Journal of Financial Economics, 9, 3-18.

Daniel, K., Hirshleifer, D., \& Subramanyam, A. 1998. Investor psychology and security market under- and overreactions. Journal of Finance, 53, 1839-1885.

DeBondt, W. F. M., \& Thaler, R. H. 1985. Does the stock market overreact? Journal of Finance, 40, 557-581.

Edwards, W.1968. Conservatism in human information processing. In B. Kleinmutz, ed : Formal Representation of Human Judgement. NY: Wiley.

Fama, E. F., \& French, K. R. 1992. The cross section of expected stock returns. Journal of Finance, 47, 427-465. 
Fama, E. F. 1998. Market efficiency, long-term returns, and behavioral finance. Journal of Financial Economics, 49, 283-306.

Festinger, F. 1957. A theory of cognitive dissonance. Stanford, CA: Stanford University Press.

Filbeck, G. 2001. Mother Jones: Do better places to work imply better places to invest? Review of Financial Economics, 10, 57-70.

Gervais, S., \& Odean, T. 2001. Learning to be overconfident. Review of Financial Studies, 14, 1-27.

Grinblatt, M., \& Han, B. 2005. Prospect theory, mental accounting, and momentum. Journal of Financial Economics, 78, 311-339.

Grinblatt, M., \& Keloharju, M. 2001. How distance, language, and culture influence stockholdings and trades. Journal of Finance, 56, 1053-1073.

Hirshleifer, D. 2001. Investor psychology and asset pricing. Journal of Finance, 56, 15331597.

Jegadeesh, N., \& Titman, S. 1993. Returns to buying winners and selling losers: implications for stock market efficiency. Journal of Finance, 48, 65-91.

Jensen, M. C. 1986. Agency costs of free cash flow, corporate finance, and takeovers. American Economic Review, 76, 323-329.

Kahneman, D., \& Riepe, W. 1998. Aspects of investor psychology. Journal of Portfolio Management, Summer, 24, (4), 52-65.

Kahneman, D., \& Tversky, A. 1973. On the psychology of prediction. Psychological Review, 80, 237-251.

Kahneman, D., \& Tversky, A. 1979. Prospect theory: An analysis of decision under risk. Econometrica, 47, 263-291.

Kahneman, D., \& Tversky, A. 1982. Intuitive predictions: biases and corrective procedures. Reprinted in Kahneman, Slovic, \& Tversky, Judgement under Uncertainty: Heuristics and Biases. Cambridge University Press, Cambridge, England.

Kothari, S. P., Jonathan , L., \& Warner, J. B. 2006. Stock returns, aggregate earnings surprises, and behavioral finance. Journal of Financial Economics, 79, 537-568.

Lakonishok, J., Shleifer, A., \&. Vishny, R. 1994. Contrarian investment, extrapolation, and risk. Journal of Finance, 49, 1541-1578.

Markowitz, H. 1952. The utility of wealth. Journal of Political Economy, 60, 151-158.

Roll, R., \& Ross, S. A. 1994. On the cross-sectional relation between expected returns and betas. Journal of Finance, 49, 101-121.

Sherfin, H., \& Statman, M. 1994. Behavioral capital asset pricing model. Journal of 
Financial and Quantitative Analysis, 29, 323-349.

Sherfin, H., \& Statman, M. 2000. Behavioral portfolio theory. Journal of Financial and Quantitative Analysis, 35, 127-151.

Simon, H. A. 1955. A behavioral model of rational choice. Quarterly Journal of Economics, 69, 99-118.

Solt, M. E., \& Statman, M. 1989. Good companies, bad stocks. Journal of Portfolio Management, Summer, 15 (4), 39-45.

Statman, M. 1999. Behavioral finance: Past battles and future engagements. Financial Analyst Journal, Nov-Dec, 18-27. 
Contemporary Management Research 140 